\title{
WATER AND CLIMATE: COULD THESE ELEMENTS CONCERN SCOTLAND? A BRIEFLY ANALYSIS OF SOME AR5 SCENARIOS
}

\author{
BEREZUK, Andre Geraldo - andreberezuk@ufgd.edu.br, \\ Universidade Federal da Grande Dourados / UFGD \\ IORIS, Antonio Augusto Rossotto - IorisA@cardiff.ac.uk \\ Cardiff University / Wales, United Kingdom
}

\begin{abstract}
The climatic models and their scenarios are important tools to describe how could it will be the climatic patterns within nation territories. Moreover, these models are important technical tools for developing strategical territory actions. Following this idea, the aim of this paper is to analyse possible future climatic scenarios for Scotland among XXI century. Scotland is an important nation which integrates the United Kingdom and it has a significant water quality level in Europe. Furthermore, Scotland has an advanced water policy that is strongly linked with Water Framework Directive rules. For developing a briefly Scotland's climatic report, this paper describes the main results of two Europe climatic models from AR5 (one created by Collins at al. apud IPCC, 2013; and another model created by Christensen \& Kanicharla apud IPCC, 2013).
\end{abstract}

Keywords: Scotland, climatic models, water, prognosis

ÁGUA E CLIMA: PODERIAM ESTES ELEMENTOS PREOCUPAR A ESCÓCIA? UMA BREVE ANALISE DE ALGUNS CENÁRIOS AR5

RESUMO: Os modelos climáticos e seus cenários são importantes ferramentas para descrever como poderão ser os padrões climáticos no contexto das nações e seus territórios, além destes modelos serem importantes ferramentas técnicas para 0 desenvolvimento de ações estratégicas territoriais. Seguindo este princípio, este artigo tem como objetivo analisar possíveis cenários futuros para a Escócia, ao longo do século XXI. A Escócia é uma importante nação que integra o Reino Unido e possui um significativo potencial hídrico na Europa, especialmente em termos qualitativos. No mais, este país possui uma política hídrica avançada, fortemente relacionada às regras da Diretiva das Águas da Europa. Para o desenvolvimento de um conciso relatório climático sobre a Escócia, este artigo descreverá os principais resultados de dois modelos climáticos Europeus inseridos no AR5, modelos estes criados por Collins at al. apud IPCC (2013) e Christensen \& Kanicharla apud IPCC (2013).

Palavras- chaves: Escócia, modelos climáticos, água, prognoses.

\section{INTRODUCTION}

Water is a vital element for the planet and every national water policy should show ways to explain clearly its principles. More than that, it is main important that every country seeks to strengthen its efforts to report carefully its own water potential and its physical characteristics of the landscape, in special understanding its own climatic aspects. Thus, the knowledge of water resources and climatic aspects of a territory is connected to the territory actions and opens a possible understanding of some prognosis that would be connected 
with physical and chemical changes between these two aspects. Water diagnosis and prognosis and, also, climatic aspects from a territory are essentials to develop an efficient environmental and water policies. Following these concepts, we want briefly to show a case study about Scotland, which is an important part of United Kingdom and an important nation of Europe. The aims of this article are:

1) Showing some model results created by Assessment Report 5 (Intergovernmental Panel on Climate Change - IPCC) to Europe (Collins at al. apud IPCC, 2013; Christensen \& Kanicharla apud IPCC, 2013) and discussing its relevance to Scotland territory among 21th Century;

2) Developing a briefly report of possible environmental macro-impacts which could affect Scotland and Europe.

Notwithstanding, why Scotland? At first, Scotland is a nation which has a very high level of water quality, specially within Highlands or Hebrides regions. Rivers and brooks of these regions are classified as ones of the most pure waters in the world. Many Scottish traditions, as whisky production or salmon and trout fishing activities, are only be possible because its top quality waters. Even Silicon Glen region waters (industrial area between Edinburgh and Glasgow which lives the majority part of five millions of Scots) has good standards of water quality, despite of the fact that this area presents spots of polluted water as well.

Another important aspect to think about this issue is the fact that Scotland has a modern water policy scope inside the overall context of the European Union water policies, especially about its technical and methodological characteristics. Explaining Scotland's water and climatic aspects, even in a briefly mode, is a way to protect and to contribute with Scottish water strategies. Analysing Scotland's water, its climatic aspects and its possible scenarios means to understand a bit more of United Kingdom and its geopolitical importance inside Europe scope.

\section{MATERIAL AND METHODS}

At first, we should explain that it is not a task of this article to analyse the efficiency of the climatic models that are being used by IPCC nor to develop comparisons between one model against others. Thereby, the core materials for developing this briefly Scotland's climatic report will be based on Europe's climatic models created by Collins at al. apud IPCC (2013), Christensen \& Kanicharla apud IPCC (2013) and Europe's temperature and precipitation data and prognosis by Collins at al. apud IPCC (2013). In other words, the technical development of this work is embased by the perspective that these models and data have an acceptable quality.

In this regard, the methodology proceedings of this research is basically analyse these climatic models and data results for Europe and explain these statistics within a possible Scotland's prognosis. We trust that both climate models and data results mentioned are reliable, for this are based on IPCC data. 


\section{RESULTS AND DISCUSSION}

\subsection{GEOGRAPHICAL ASPECTS OF SCOTLAND'S WATER, CLIMATE AND HYDROGEOLOGY}

Scotland's territory is located at the north sector of United Kingdom, and it has an extension of 78.772 kilometres square. Its area is characterized by a rich drainage net where the main rivers are: river Tay (193 kilometres of extension), river Spey (172 kilometres of extension), river Clyde (171 kilometres of extension), river Tweed (156 kilometres of extension) and river Forth (105 kilometres of extension) (Scotland Government site).
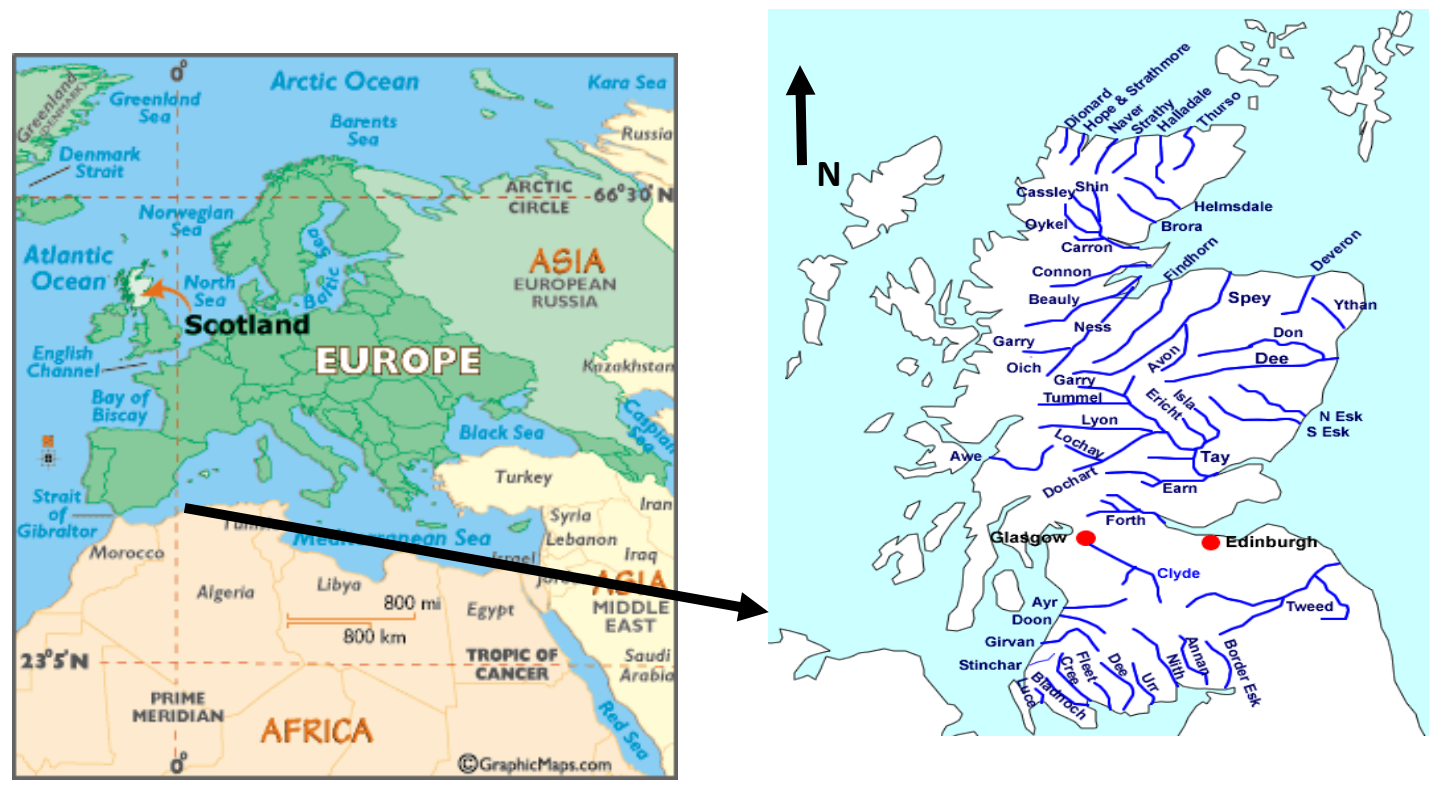

Figure 1 - Scotland's major rivers map. Sources: http://www.fishingscotland.net/rivers-map.htm;

http://www.worldatlas.com/webimage/countrys/europe/uks.htm - access on march 2016.

In general, the main water source of these rivers is the thaw of mountain areas, as Grampian's and Cainghorn's sectors. Nevertheless, this territory has large lakes as Ness, Lomond, Morar, Leven, Drunkie, Kathrine, Lubnaig, among others. Scotland's water net drainage and groundwater resources are deeply entangled with a constantly pluvial rhythm (there are not drought seasons normally, with frequent rains all year). Moreover, Scottish pluvial rhythm is characterized by showing larger quantities of rain at the west coast of its territory, where the pluviometrical level reaches two thousand millimetres every year. This average amount of rain on Scotland's west coast is one of the highest rain levels in Europe (for example, Glasgow is considered the wettest large city of Great Britain and Europe). Nevertheless, the amount of annual average of rain decreases to seven hundred millimetres annually in the east coast of Scotland. This relevant difference between west and east coast is very likely to 
be explained by the processes of convective rains within west coast, and these rains become less intense when the wet systems overpass the Highlands region.

Thus, one of the most relevant aspects about Scottish climate patterns is regarded the fact of the constancy of its rain pattern. Although seasonal aspects are determinant when we analyse Europe rain patterns (e.g. Meridional Europe or Mediterranean Europe), there is a strong stability within Scotland's pluvial rhythm. This pattern is explained because of two aspects:

1) the presence of the westerlies which create the cold fronts and storms;

2) the higher water temperature of Scottish western coast which is higher than its neighbour areas because of Gulf Stream influence. Gulf Stream provides higher levels of water condensation inside an environment that has normally high rates of humidity, indeed. In that way, unstable weather patterns is often developed, and its clouds originate rain at western coast. When this unstable weather overpass the country, the rain often continues but with less intensity on east sector. The constancy of Scotland's pluviometrical rhythm characteristic is a fundamental and strategical factor of its landscape and it is a highly entangled characteristic of Scotland's culture itself. For this reason, every change in rain rhythm could be a serious threat for many strategical sectors of this country.

More than Scotland's advantage referred to its constant pluviometrical rhythm, this territory has a second positive point: it does not have high oscillations on its daily temperatures. It happens because of three reasons:

1) the action of the frequent rains;

2) the presence of Gulf Stream, which contributes with mild average temperatures if we consider its latitudes;

3) the few quantity of heat stroke hours on its territory if we compare with other near regions (e.g England, France, Netherlands, among others). Few quantity hours of heat stroke result in less evapotranspiration rates, which permits these regions with low millimetres of annual rain (e.g. $700 \mathrm{~mm}$ of annual rain at East Coast) do not suffer with drought periods.

A possible threat for a territory which has a regular pluviometrical rhythm is the possibility of a low resilience ${ }^{1}$ level on its landscape configuration. Thus, a way to analyse Scottish landscape resilience is knowing if this territory has enough water resources that can be explored when it is passing for some unusual but real drought season. So, when we describe water resources, it is important to understand the groundwater configuration and have a diagnosis of the geological substract.

Observing a Scottish geological map (figure 2), there are Ordovician, Carboniferous and Devonian geological formations that are located at the south and centre-south regions of Scotland. Silicon Glen and Lowlands regions are

\footnotetext{
${ }^{1}$ Resilience - Quoting Folke et. al. (2002) is defined as: "(i) the magnitude of shock that the system can absorb and remain within a given state; (ii) the degree to which the system is capable of selforganization; and (iii) the degree to which the system can build capacity for learning and adaptation. Management can destroy or build resilience, depending on how the social-ecological system organizes itself in response to management actions".
} 
especially located at these geological areas and this aspect is a positive one, aiding Scotland's resilience level. However, at central, north-east and north regions (Highlands area), geological formations are constituted by metamorphic and igneous rocks, and these geological formations have little or even nonhydric potential to constitute an aquifer. In that way, better hydrogeological areas are located at the same place of more inhabited areas, which could contribute with a better resiliency level on Scottish territory, when we are discussing specifically about water. Also, it means a natural resiliency aspect of the landscape to support future climatic changes and extreme weather events.

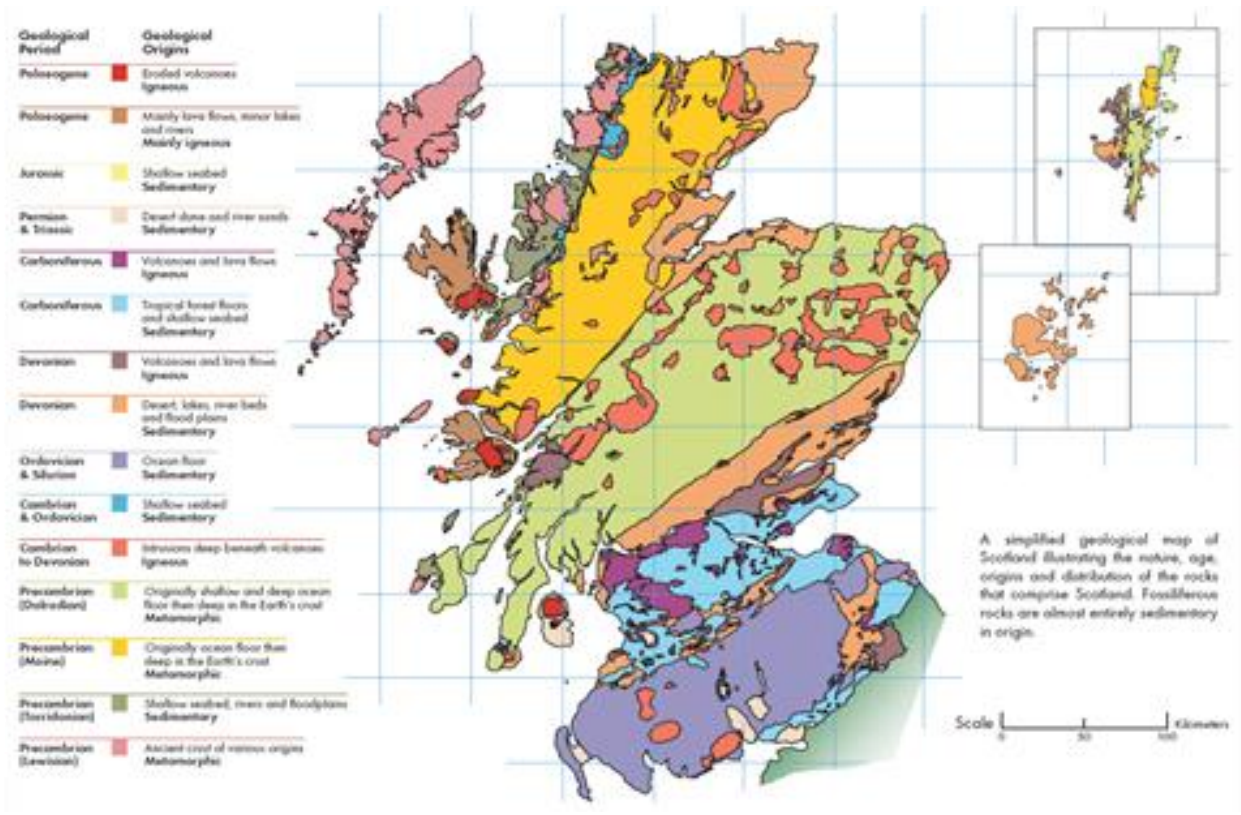

Figure 2 - Scotland's Geological Map. Source: Scottish Geology http://www.scottishgeology.com/wp-content/uploads/2012/01/map1.jpg

Na Tabela 2 estão descritas as frequências dos acumulados de A better knowledge on climatic and geological aspects of Scotland becomes possible a better comprehension of the territorial resilience against likely climate changes future scenarios. Notwithstanding, what could some future climatic scenarios reveal to Scotland?

\subsection{CONSIDERATIONS ABOUT CLIMATIC CHANGES IN SCOTLAND AND EUROPE}

If we accept that Scotland has a very good water potential and a pluvial constancy about its pluviometrical rhythm, it is important to analyse what will be the possible future scenarios for this nation through XXI Century. For that, we could start this issue showing some projections of Assessment Report 5 (IPCC, 2013) to North Europe. These scenarios are about rain and temperature prognosis for North Europe, which can be used to report a briefly Scotland's prognosis (Figures 3, 4 and 5).. 

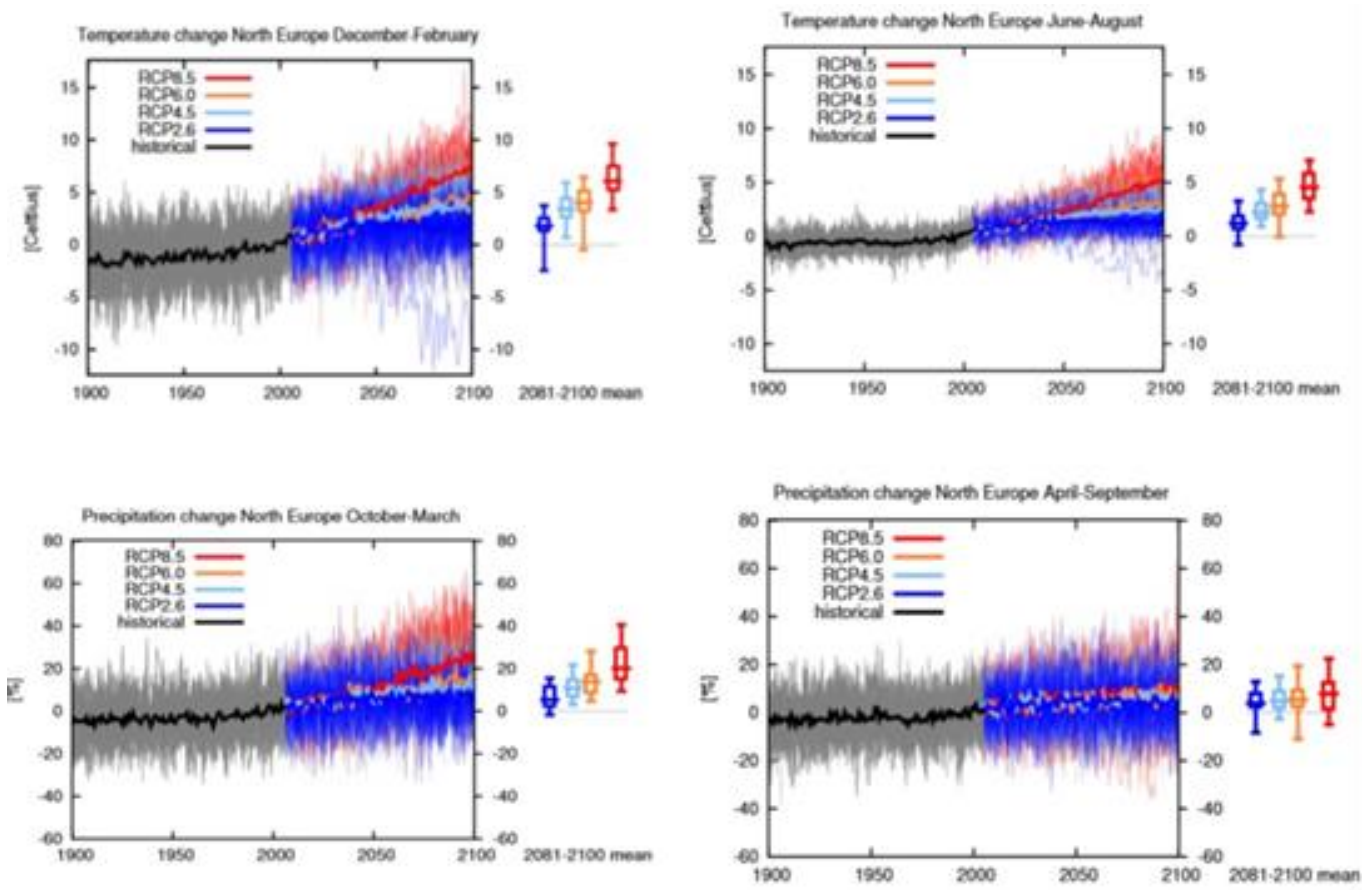

Figure 3 - Temperature and rain prognostics at North Europe until year 2100. Source: COLLINS, M. et. al., AR5, ANNEX I, pages 2091 to 2094, 2013. (The organization of the graphics were made by the authors).

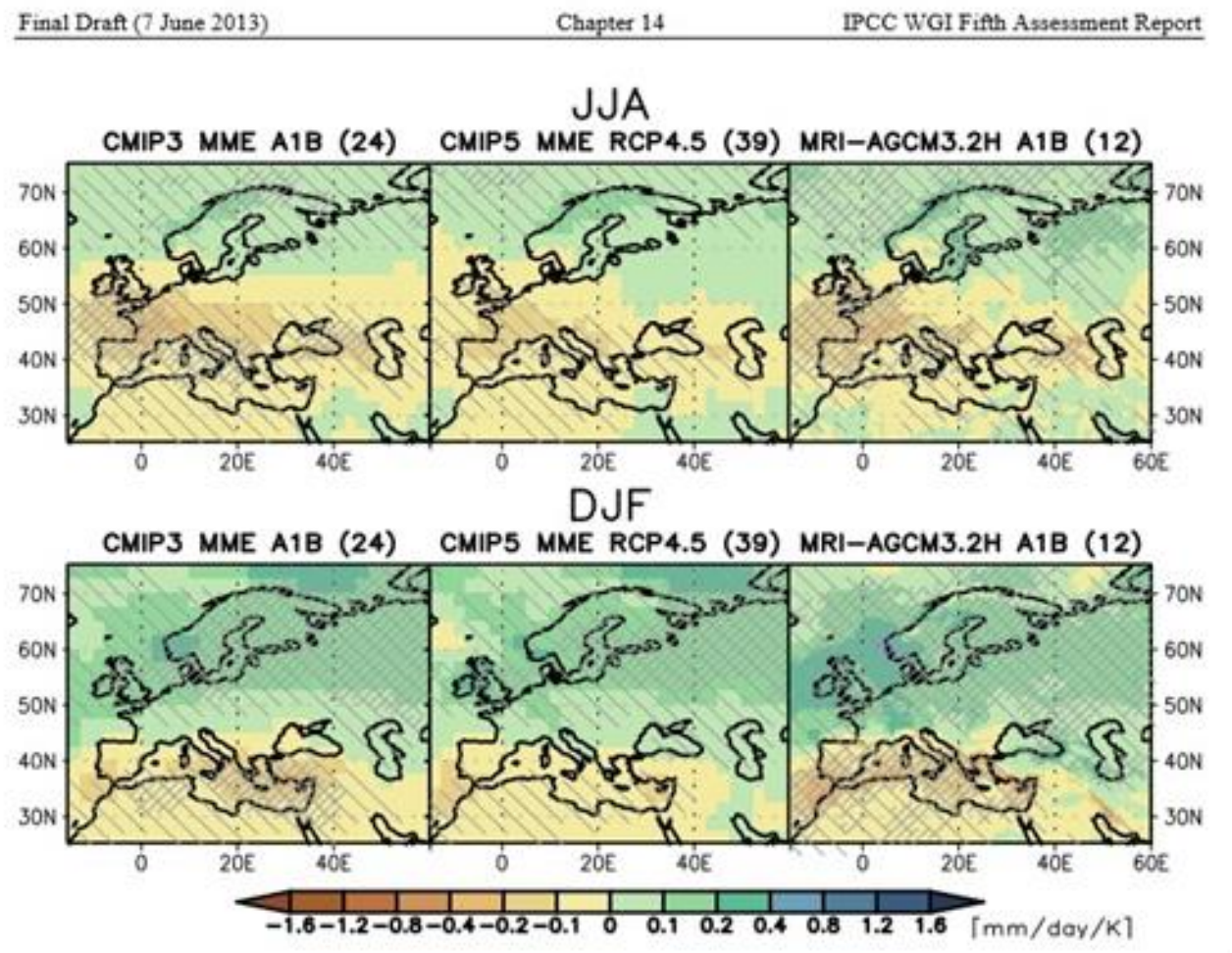

Figure 4 - Pluviometrical scenarios in Europe among 21th Century (summer and winter seasons). Source: CHRISTENSEN, J. H.; KANIKICHARLA, K. K. AR5, Chapter 14, page 2044, 2013, figure 14.22 . 

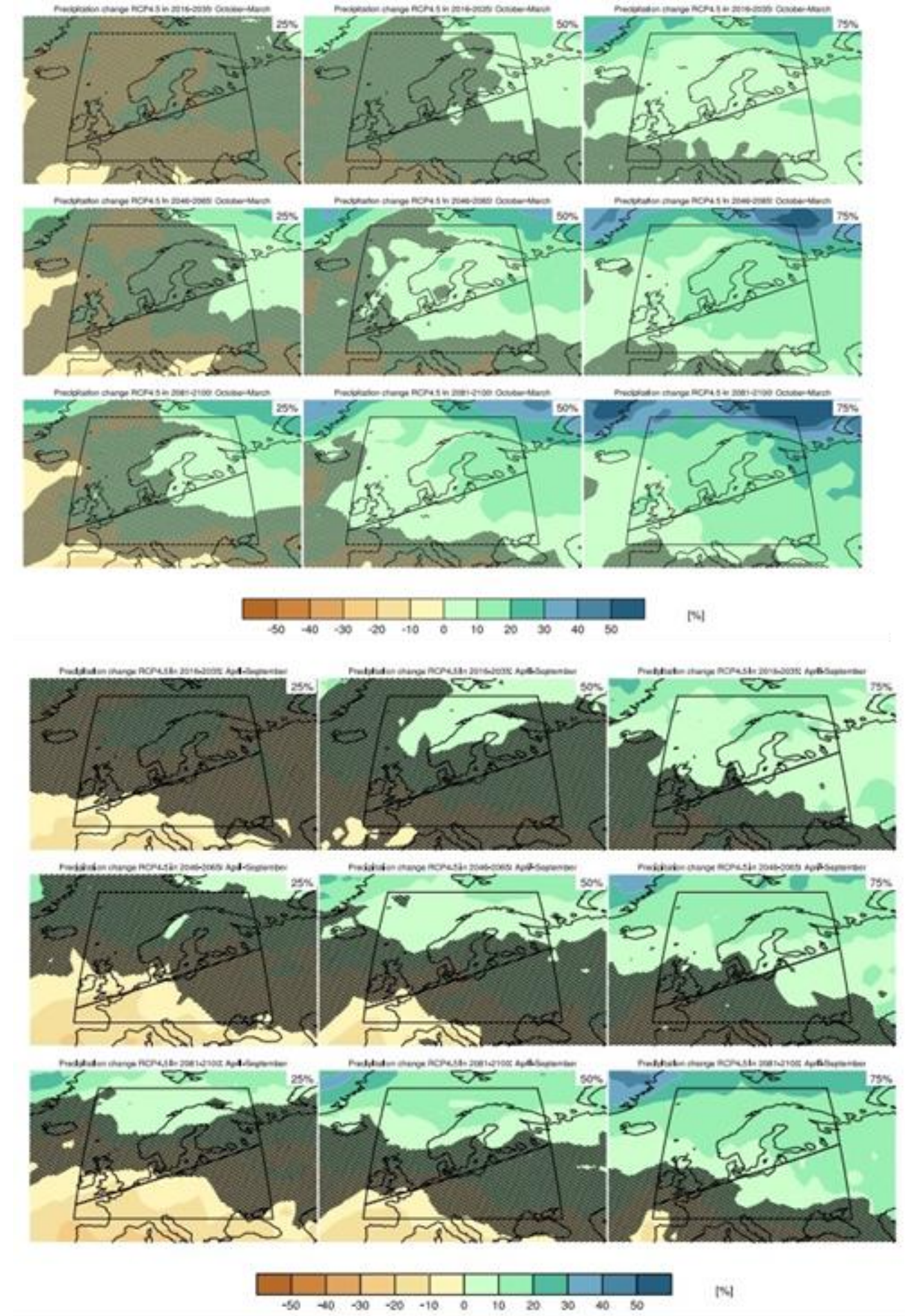

Figure 5 - Pluviometrical scenarios in Europe among 21th Century (summer and winter seasons). Source: COLLINS, M. et. al., AR5, ANNEX I, pages 2093-2094, 2013. (The image organization were made by the authors).

Observing these scenarios until year 2100 to North Europe, we can see that these climatic graphics (Figure 3) show a rising in 4 to $80 \mathrm{C}$ at winter 
months average temperatures, and a rise in 2 to $50 \mathrm{C}$ at summer months average temperatures. When we are searching about levels of annual precipitation, these models reveal risings up to $20 \%$ in winter rain and they show risings up to $10 \%$ in summer rain amounts.

When we are searching these images about North Europe, we could observe a tendency of rising quantities of rain in Scotland in summer and winter seasons, however, there is a possibility to be a minor rising in rain quantity when we are comparing these prognostics with Scandinavian countries or even higher latitudes. Another important aspect that could be reported is the fact that these climatic models are showing two different climatic patterns for Europe: at first, more quantity of rain and snow at North Europe, and, in the other hand, less quantity of rain and snow at South Europe.

This climatic pattern observed to south Europe (less rain and snow) is probably linked with a strengthening of North Atlantic Anticyclonic Area and Sahara Desert Area, which could have a main influence in future severe drought events at south and central regions of Europe, thus, creating strong hot waves to further areas indeed, as Germany, Poland, Ukraine or even Russia within summer season. This pattern could develop a remarkable climatic seasoning aspect as well, which could become more intense these climatic changes in south, central Europe and Russia with presence of more hazards events (Figures 4 and 5).

About Scotland territory, it is possible to interpret that its area could be geographically located between wet and dry macro-areas in Europe, considering these scenarios at AR5. In other words, it could be possible a pattern configuration that Scotland could be located inside a climatic transition zone among 21st century. Analysing the current Scottish pluviometrical pattern and a greater resilience of a wetter pattern without a strong influence of Sahara's Desert hot and dry air to higher latitudes, this hypothesis could turn out a good aspect to Scotland. Nevertheless, we know that storms and flood events are not harmless and really cause damages and even death cases, but hot waves and strong drought events could be a worse threat for Scotland's landscape configuration. In a short consideration, a wet pattern prognosis for high latitudes could offer to Scotland a climatic pattern with the same problems which this country is historically used to struggling and dealing with. In other words, a wet pattern can be better then a dry pattern for this country.

It is necessary to advise that these images and graphics do not allow a clear interpretation about how will be the intensity of extreme climatic events and their own rhythm, among 21st Century.

\subsection{DARING TO THINK ABOUT THE FUTURE}

Scotland is not free of future climatic threats, and there is a very likely tendency of rising number in climatic extreme events and the occurring of hazards in Scotland as in a whole world. This is an ordinary point, and we know that. However, there is a possibility of some positive aspects for Scotland within a world in threat: the maritime aspect of Scotland territory, the continuity of wet climatic pattern, and a possible rising in the pluviometrical amounts for North Europe until 2100 (otherwise, these factors could stop some excessive rising in its thermal amplitude). It means that Scotland could be less impacted on tough 
temperatures within daily or even monthly amplitudes in the future, when we compare Scotland to its neighbour countries, in special countries that are located further south.

Water could be found with good quantity and quality inside Scotland landscape if the wet climate pattern prognosis would be confirmed. This climatic configuration could turn this region of the United Kingdom into a territory with good water resources in a world frame with chronic caress of water. Thus, Scottish water policy should continue with its efforts to develop its water system management, and there is no doubt that these actions will be very important for accessibility and consumption of water.

Nevertheless, the major threat of this territory could be the formation of a more hot and dry climatic pattern showing a more seasonality climatic rhythm, with a more influence of hot wave events or even drought periods. This drier and hotter pattern could cause more damage for this nation, for this it has never had experienced thermometers reaching up to $350 \mathrm{OC}$ (95oF). Flood events and strong storms must not be underestimated, but drought periods and hot waves are atmospheric configurations that are considered threatening and even odd ones by Scotland institutes and offices.

Having a Europe with a drier and hotter climatic pattern is a serious threat for many countries as Portugal, Spain, Italy, Greece, France, Austria, Switzerland, Germany, Hungary, Romania, Bulgaria and even eastern countries in Europe as Ukrainian, Poland, White Russia, Moldavia and the European part of Russia. All this broad area could suffer with higher temperatures and less precipitation averages. Higher temperatures and severe droughts certain would impact summer crops where many countries would struggle with difficult times, with their governments certainly subsidizing their internal food production. In fact, summer season has a historical importance to Europe because of the fact that winter season is assumed to be substantially cold for crop production yet.

More than reporting the agriculture sector, the hotter and dryer climatic pattern often would affect public health and energy sectors, in special because of the major number of homes that have been built to support the winter temperatures. For example, people were hugely affected by this situation happened in Europe on 2003, with hot and dry air mass configuration which strongly impacted on the inhabitants in Western Europe, specially the elder ones.

It is relevant to emphasize that this interpretation between wet and dry climatic patterns only will have some credit with the maintenance of atmospheric and hydrological characteristics of the Gulf Stream. Gulf Stream has a main role at higher evaporation levels, on the process of clouds formation, and constancy of seasonal and annual quantities of rain in Western and NorthWestern Europe, which contributes with not so wide thermal amplitudes. However, the knowledge and study of physical water-air interface processes still feature a very difficult and uncertain point within meteorology and climatology researches. In that way, the development of this theme has entangled Gulf Stream as strategical for a better orientation of geopolitical actions on Scotland and United Kingdom, Ireland, Iceland, Scandinavian countries and all Western Europe as well. 
Considering a frame of a future world affected by more frequent and intense extreme climatic events and hazards, places in the planet with good water stores will be highly valorized. It means that Scotland and United Kingdom will have a strategic geopolitical position if the wet climatic pattern continue to support these territories. In fact, with the development of a wetter scenario, Scotland and United Kingdom should developed accurate policies to avoid future conflicts against nations which would not have the same water potential and similar climatic configuration on its territories.

Another phenomenon that would happen is a strength of migration waves to places which are going to have better physical configurations on its territories, and these migration waves could be occur from another parts of Europe Continent and from the whole world as well. This affirmation could be joined with the global northern lands valorization hypothesis by Smith (2011), which could be theoretically linked with the traditional "daisy model" of Lovelock (2006). We should remember that the development of policies for aiding the migration issue is a real challenge for all the planet, and it can become more critical when we observe a deeper difference between rich classes and poor classes inside social structures which could contribute with a worse scenario within a climatic crisis. A wise way for a better migration policy development could be the creation of a non-extreme social policy (avoiding xenophobic social waves, types of prejudice and racial conflicts inside domestic and external scale). However, in the other hand, it would be essential to pay attention for avoiding a very liberal policy creation, which really would leave Scottish and British territories without a minimum level of security (which could leave these territories upon a vulnerable position against a broad invasion of migrants and being vulnerable these areas for an economic, social and state collapse).

Migration issue is a point that would not be ignored when we are reporting about climatic prognosis in Europe or even in the whole world (specially when we identify a future global period with more extreme climatic patterns and a water issue showing a more delicate scenario). How can we could achieve the delicate balance to develop this issue without creating a war or an atmosphere of social hatress? It could be possible if a European migration policy should be developed right now, towards a development and strength of a more intense multicultural Europe. These actions are being developed at this present time in some European countries (e.g. Germany and Norway), with a massive and growing non-European populations living inside this continent. A strength of a multicultural Europe, where all citizens must respect state common rules and have the same rights and appointments, is being implemented and it is a positive aspect to avoid an explosive social environment inside these countries. However, if these nations will start to think and discuss about this matter only in a future time, this point probably could be redirected for an authoritarian and conservative point-of-view, leaving the migration question for an extreme rightwing tendency where Human rights could not be respect, maybe bringing this continent and the planet to a very likely war period.

\section{CONCLUSIONS}

At this sector of the paper, we can conclude three main topics about Scotland water and climate scenarios and about its possible strategical actions: 
1) Scottish territory and landscape could still maintain a remarkable presence of rain and water inside its territory, when we are analysing these AR5 climatic models. It means a very likely possibility of a large number of extreme climatic events if the prognosis of wetter climatic pattern configuration will be confirmed for North Europe. However, a possible continuation of rain levels and low thermal amplitudes pattern within Scottish territory could become a positive aspect when it is compared to its neighbours located in lower latitudes (places which would suffer from drier and hotter conditions by AR5 climatic models). Nevertheless, this hypothesis only could be really confirmed if the hydrological and atmospheric characteristics of the Gulf Stream should be kept constant, without significant modifications on its physical configuration;

2) Scotland and United Kingdom physical configuration territories and the AR5 climatic models proposed by Collins at al. apud IPCC, 2013; and Christensen \& Kanicharla apud IPCC, 2013 (about a future wetter and a dryer climatic patterns dividing geographically the European Continent) could be an object of study aiming for better development policies reformulations (especially about environmental and migration policies). Moreover, the European Union should develop not so conservative policies to European and non-European citizens (to avoid xenophobia or some internal and/or external social conflicts) but, by other side, these policies should not to be so excessively liberal (to avoid a dangerous economic, social and security situation). The main goal of these policies is to create rigorously what will be the political rules that will regulate environmental and migration strategical points to avoid critical periods between these two matters in a coming future;

3) This paper believes in a future wet pattern tendency for Scotland and United Kingdom (according to Collins at al. apud IPCC, 2013 and Christensen \& Kanicharla apud IPCC, 2013). It could mean a territory with good quantity and quality of water within a critical water global frame, even if this wet pattern could bring more presence of storms and hurricanes. This prognosis could strengthen the migration issue to this area. Because of that, this paper emphasizes again the importance of a well structured national migration policies to avoid a racist, isolation and prejudice social future scenario within European Northern countries (e.g. Great Britain and Scotland), specially considering countries localized in lower latitudes which could be affected by hotter and drier climatic patterns and water crisis, indeed. Achieving a balanced level inside this difficult and polemical task is definitively not a practical and easy work, but it certainly could avoid conflicts, terrorism acts and war events within a world that is going to look passionately for better landscapes with water in a soon future.

\section{ACKNOWLEDGEMENTS}

Andre Geraldo Berezuk would like to express his gratitude:

1) to Institute of Geography and School of Geosciences of The University of Edinburgh, Scotland, for the unique opportunity of developing his post-doctoral (sabbatic time) research; 
2) to Laboratory of Physical Geography of Federal University of Grande Dourados - Brazil, because of the material support, in special for Dr. Charlei Aparecido da Silva;

3) to Brazilian Council for Scientific and Technological Development (CNPq) for this research was supported under Grant number 200805/2015-0.

\section{REFERENCES}

CHRISTENSEN, J. H.; KANIKICHARLA, K. K. Climate Phenomena and their Relevance for Future Regional Climate Change In: Working Group I: contribution to the IPCC Fifth Assessment Report (AR5), Climate Change 2013: the Physical Basis. Intergovernmental Panel on Climatic Change, United Nations, 2013.

COLLINS, $M$. et al. ANNEX I: ATLAS OF GLOBAL AND REGIONAL CLIMATE PROJECTIONS In: Working Group I: contribution to the IPCC Fifth Assessment Report (AR5), Climate Change 2013: the Physical Basis. Intergovernmental Panel on Climatic Change, United Nations, 2013.

FOLKE, C. et. al. Resilience and Sustainable Development: Building Adaptive Capacity in a World of Transformations. Ambio, Vol. 31 No. 5, Aug. 2002. pp. 437-440.

LOVELOCK, J. La Venganza de la Tierra: la teoría de gaia y el futuro de la humanidad. (Tradução de Mar García Puig). Barcelona : Planeta, 2006. 249 p.

SALMON FISHING MAP SCOTLAND'S RIVERS - http://www.fishingscotland.net/rivers-map.htm - access in march 2016

SCOTIISH GEOLOGY - $\quad$ http://www.scottishgeology.com/wpcontent/uploads/2012/01/map1.jpg - Image reproduced by kind permission of The trustees National Museums Scotland - access in March 2016

SCOTLAND GOVERNMENT. http://www.scotland.org/about-scotland/where-isscotland/scotlands-geography/ - access in March 2016

SMITH, L. C. O mundo em 2050: como a demografia, a demanda de recursos naturais, a globalização, a mudança climática e a tecnologia moldarão o futuro. Rio de Janeiro : Elsevier, tradução de Ana Beatriz Rodrigues, 2011. 274 p.

WORLDATLAS - http://www.worldatlas.com/webimage/countrys/europe/uks.htm - access in March 2016 